\title{
Secondary Metabolites and Antioxidant Potentials of Axis Sea Bamboo (Isis hippuris)
}

\author{
Mohammad Sayuti ${ }^{1}$, Widya Dwi Rukmi Putri ${ }^{2}$ and Yunianta ${ }^{2}$ \\ ${ }^{1}$ Polytechnic Marine and Fishery of Sorong, West Papua, Indonesia \\ ${ }^{2}$ Faculty of Agriculture Technology, Brawijaya University, Malang, Indonesia
}

(Received: April 28, 2018; Accepted: December 18, 2018; Published (Web): April 01, 2019)

\begin{abstract}
Secondary metabolites of the axis section (modulla skeleton) of sea bamboo (Isis hippuris) were identified by GC-MS. The dominant compounds using GC-MS in the ethanol fraction were hexanedioic acid $(11.85 \%)$, acetamide $(9.46 \%), n$-hexadecanoic acid $(9.22 \%)$ and thiosulfuric acid $(7.22 \%)$. On the other side, the dominant compounds of the test results in the ethyl acetate fraction were 7-oxabicyclo[4.1.0] heptanes (28.27\%), 1,2benzene dicarboxylic acid (14.77\%), cis-8-(N-pyrrolidyl)-(2,2,5,5-tetradeutero)bicyclo[4.3.0]nona-3,7-diene (9.98\%), hexahydropyridine $(7,86 \%)$. The dominant compounds of the $n$-hexane fraction were hexanedioic acid $(41.99 \%)$, azetidine with a peak number of $40(9.98 \%), 1$-octadecene $(8,36 \%)$. Antioxidant activities were also evaluated by DPPH scavenging assay. The ethanol, $n$-hexane and ethyl acetate fractions showed total flavonoid contents of $7.86 \%$ $\pm 0.12,12.97 \% \pm 0.36,1.88 \% \pm 0.26$, respectively and the $\mathrm{IC}_{50}$ in the antioxidant assay were $480.25 \pm 74,74$, $469.50 \pm 19,13,3221.07 \pm 138,69$ respectively.
\end{abstract}

Keywords: Sea bamboo, Isis hippuris, antioxidant, gas chromatography-mass spectrometry (GC-MS)

\section{INTRODUCTION}

Over the past decade, numerous studies have focused on the bioactive compounds identification in marine organisms ${ }^{1}$, many of which belong to coral reefs. Located in the tropics, Indonesia has a high biodiversity, particularly coral reefs. Indonesia has about 450 species of corals and 70-80 coral genera. It has two-thirds coastline with a coastline length of more than $80,000 \mathrm{~km}$. Coral reef ecosystems are distributed over more than 50,000 kilometers. ${ }^{2}$ The rich potential of these coral reefs is a valuable natural resource.

One of the constituents of coral reefs is soft corals (Octocorallia). This class is represented by the Gorgonacea family, which is the class of soft corals widely found in the Indo-Pacific ocean and several other areas, especially in the tropics. Soft corals are the second largest component of coral reefs after

Correspondence to: Mohammad Sayuti

E-mail: mohsayut@gmail.com

Phone : +6281384110423

Dhaka Univ. J. Pharm. Sci. 18(1): 13-20, 2019 (June) DOI: https://doi.org/10.3329/dujps.v18i1.41422 hard/stony corals (Zoanthatiria). In some areas with damaged coral reef habitats, soft corals have become the major constituent. ${ }^{3}$

Along with advances in science and technology, experts have been diligently conducting research on soft corals. New findings in the pharmaceutical field are very useful for human health applications, such as the discovery of chemicals that can be used as medicinal materials, antibiotics and antitumor substances. Pharmacologists and biochemists are constantly searching for new medicinal products that can be extracted from materials derived from Octocoralia corals. ${ }^{4}$ One type of Gorgonacea with economic value is sea bamboo (Isis hippuris), which is thought to contain various compounds that can be used in both the pharmaceutical and biochemical industries. Sea bamboo skin (outer layer) contained secondary metabolites such as alkaloid, flavonoid, phenol, steroid, and saponin, while the axial contained alkaloid, flavonoid, phenol, and steroid. ${ }^{5}$ The aim of this research was to investigate the antioxidant activity and secondary metabolites of the axis section of sea bamboo. 


\section{MATERIALS AND METHODS}

Sample preparation. Sea bamboo (Isis hippuris) were collected from Biak Sea, Papua, at a depth of 3-10 m. It was cleaned and dried for 7 days. The skin and axial (inside) sections of dried sea bamboo samples were separated. Both parts were finely crushed using a machine to obtain powdered samples. The powdered samples were then stored until use.

Extraction and fractionation. The extraction process employed an ultrasonic method using the Branson Ultrasonic tool (3510). Twenty gram of sea bamboo axis powder (I. hippuris) was placed into an Erlenmeyer flask. Methanol was added to obtain a ratio of $1: 10$, then the sample was covered with aluminum foil. The extraction was performed using ultrasonic waves at $35^{\circ} \mathrm{C}$ for $20 \mathrm{~min}$. Then, the extracted substances were filtered using filter paper and a vacuum filter tool. The filtrate was then evaporated to leave only the solid extract, which was collected and stored at $0^{\circ} \mathrm{C}$.

The solid extract was fractionated using a separatory funnel using solvents with different polarities. The first solvent mixture included $n$ hexane and ethanol at a ratio of $2: 1$. The sample was added, stirred and then it was left to separate into two layers. The $n$-hexane fraction was then evaporated, while the ethanol fraction was re-fractionated using ethyl acetate at a ratio of 2:1. At the end of the fractionation, there were three fractions, the $n$-hexane fraction, ethanol fraction and ethyl acetate fraction. These were all stored at $0^{\circ} \mathrm{C}$ for further tests. Before being stored, each fraction was evaporated to dryment and weighed to determine the yield using the following formula:

Yield $=\frac{\text { Dried extract weight }}{\text { Initial sample weight }} \times 100 \%$

Determination of the total phenol content (TPC). The total phenolic substances from fractionation of the sea bamboo axis were determined using the published method. ${ }^{6-8}$ The first step was to generate the gallic acid curve by creating gallic acid. Serial dilutions of $0,4,15$ and $20 \mathrm{ppm}$ were used, to which up to $5 \mathrm{ml}$ of distilled water and $0.5 \mathrm{ml}$ of $50 \%$ Folin-Ciocalteu reagent were added. The mixture was incubated for $5 \mathrm{~min}$, then $1 \mathrm{ml}$ of $5 \% \mathrm{Na}_{2} \mathrm{CO}_{3}$ was added. The mixture was homogenized and incubated in the dark for $1 \mathrm{~h}$. The absorbance was then measured three times using a UV-Vis spectrophotometer at $725 \mathrm{~nm}$. The gallic acid standard curve was created using the equation $\mathrm{Y}=\mathrm{ax}+\mathrm{b}$, where $\mathrm{Y}$ is absorbance and $\mathrm{x}$ is the concentration of gallic acid. The second step was to determine the total phenol content by dissolving $5 \mathrm{mg}$ of the dried extract in 2 $\mathrm{ml}$ of ethanol PA, to which up to $5 \mathrm{ml}$ of distilled water and $0.5 \mathrm{ml}$ of $50 \%$ Folin-Ciocalteu reagent were added to the mixture. The solution was incubated for $5 \mathrm{~min}$. After that, $1 \mathrm{ml}$ of $5 \% \mathrm{Na}_{2} \mathrm{CO}_{3}$ was added to the solution, which was then homogenized for $5 \mathrm{~min}$ and incubated in the dark for $1 \mathrm{~h}$. The absorbance of substances was measured three times using a UV-Vis spectrophotometer at $725 \mathrm{~nm}$, which was then calibrated to gallic acid standard curve, in order to obtain the total phenol content in milligrams of gallic acid equivalent (GAE) per gram of sample. The total phenol content was measured using the following equation:

$\mathrm{C}=\frac{\mathrm{C}_{\mathrm{GAE}} \times \mathrm{V}}{\mathrm{G}}$

where $\mathrm{C}$ is the total phenol content, $\mathrm{C}_{\mathrm{GAE}}$ is the total phenol in the equivalent form of gallic acid $(\mathrm{mg} / \mathrm{ml}), \quad \mathrm{V}$ is the volume of the extract and $\mathrm{G}$ is the mass of the sample $(\mathrm{g})$.

Total flavonoid analysis. Determination of total flavonoid content in the sea bamboo axis extract was performed using the reported method..$^{9-11}$ The first step was determining the standard quercetin curve by making a quercetin stock solution of $1000 \mathrm{ppm}$, then diluting the stock solution to obtain solutions of 50 , 100, 150 and $200 \mathrm{ppm}$. To this solution, $1.5 \mathrm{ml}$

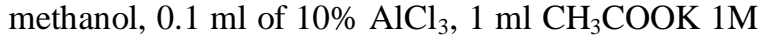
and $2.8 \mathrm{ml}$ distilled water were added. The mixture was homogenized and incubated for $30 \mathrm{~min}$. The absorbance was measured three times using a UV-Vis spectrophotometer at $415 \mathrm{~nm}$. The standard quercetin curve was generated using the equation: $Y=a x+b$, where $\mathrm{Y}$ is the absorbance and $\mathrm{x}$ is the concentration. 
The regression equation and the $\mathrm{R}^{2}$ of the quercetin standards were then determined. The second step was determining the total flavonoid content using 0.5 of the fractionation result with $1000 \mathrm{ppm}$ concentration, which was placed into the reaction tube. To this mixture, $1.5 \mathrm{ml}$ ethanol, $0.1 \mathrm{ml}$ of $10 \% \mathrm{AlCl}_{3}, 0.1 \mathrm{ml}$ $\mathrm{CH}_{3} \mathrm{COOK} 1 \mathrm{M}$ and $2.8 \mathrm{ml}$ distilled water were added. The mixture was homogenized and incubated for $30 \mathrm{~min}$. The solution absorbance was measured three times using a UV-Vis spectrophotometer at 415 $\mathrm{nm}$. The next step was calibrating the results with the standard quercetin curve to obtain the total flavonoid content, which was expressed as milligrams of quercetin equivalent divided by the weight of the extract in grams ( $\mathrm{mg} \mathrm{QE} / \mathrm{g}$ extract) or as a percentage using the following equation:

$\mathrm{C}=\frac{\mathrm{C}_{\mathrm{QE}} \times \mathrm{V} \times \mathrm{Fp}}{\mathrm{M}} \times 100 \%$

where $\mathrm{C}$ is the total flavonoid content (mg QE/g extract), $\mathrm{M}$ is the weight of the extract ( $\mathrm{g}$ ), $\mathrm{C}_{\mathrm{QE}}$ is the quercetin concentration $(\mathrm{mg} / \mathrm{ml}), \mathrm{Fp}$ is the dissolving factor and $\mathrm{V}$ is the volume of the extract $(\mathrm{L})$.

Antioxidant activity test. The antioxidant activity (AOA) was determined using the DPPH scavenging assay. ${ }^{12}$ First of all, DPPH of $0.2 \mathrm{mM}$ and ethanol was preparated. The second step was to create stock solution with a concentration of 1000 ppm in ethanol, which was then diluted to obtain concentrations of 50,100, 250, 500 and $1000 \mathrm{ppm}$. A 4-ml aliquot of each dilution was taken as the sample and reacted with $1 \mathrm{ml}$ of $0.2 \mathrm{mM}$ DPPH solution. The absorbance was then measured at $517 \mathrm{~nm}$. The same process was repeated for the blank solution without the sample. The percentage inhibition was then measured according to the following equation:

Inhibition $(\%)=\frac{\text { Absorbance blank }- \text { Absorbance sample }}{\text { Absorbance blank }} \times 100$

The regression equation for the percentage inhibition and sample concentration was:

$\mathrm{Y}=\mathrm{a}(\mathrm{x})+\mathrm{b}$

where $\mathrm{Y}$ is the measured inhibitor concentration (IC) at 50 and $\mathrm{X}$ is the $\mathrm{IC}_{50}$ value.
The $\mathrm{IC}_{50}$ value represents the sample concentration that was needed to reduce the DPPH concentration by $50 \%$.

Gas chromatography-mass spectrometric (GC-MS) analysis. The GC-MS used in this study (QP2010S) was set to an injector temperature of $280^{\circ} \mathrm{C}$, split injector mode, sampling duration of 1 min and a column temperature of $40-270^{\circ} \mathrm{C}$. The initial temperature was $40^{\circ} \mathrm{C}$, which was maintained for $10 \mathrm{~min}$ before being increased to $270^{\circ} \mathrm{C}$ (rate of $23^{\circ} \mathrm{C}$ per min) for $60 \mathrm{~min}$. The total duration of this process was 88 minutes. The detector temperature was set to $280^{\circ} \mathrm{C}$, interval temperature was $250^{\circ} \mathrm{C}, \mathrm{He}$ was the carrier gas, main pressure of 500-900, flow control mode pressure, pressure of $10.9 \mathrm{kPa}$, total flow rate of $58.8 \mathrm{ml} / \mathrm{m}$, column flow rate of 0.55 $\mathrm{ml} / \mathrm{m}$, linear acceleration of $26.0 \mathrm{~cm} / \mathrm{dt}$, cleansing acceleration of $3.0 \mathrm{ml} / \mathrm{m}$ and split ratio of 99.8 . An Rtx-5MS column was used, which had a length of $30.00 \mathrm{~m}$, the thickness of $0.25 \mu \mathrm{m}$, the diameter of $0.5 \mathrm{~mm}$ and electron impact (EI) ionization of $70 \mathrm{eV}$.

\section{RESULTS AND DISCUSSION}

Yield, total phenol and flavonoid content and antioxidant activity. The methanol extract of the axis section of sea bamboo was fractionated to provide ethanol (polar), ethyl acetate (semi polar) and $n$-hexane (nonpolar). Fractions test were conducted to determine the yield (rendement) and the total phenol and flavonoid content. These results are presented in table 1 .

The high $\mathrm{IC}_{50}$ values indicate that the antioxidant activities of the fractions of sea bamboo axis can be classified as very weak as they were above $400 \mathrm{ppm}$. A compound considered to have a very strong, strong, moderate weak, very weak antioxidant activity if the $\mathrm{IC}_{50}$ value is less than $50 \mathrm{ppm}$, between 50-100 ppm, between 100-150 ppm, between 150$200 \mathrm{ppm}$, and above $200 \mathrm{ppm}$; respectively. ${ }^{12}$ The weak antioxidant activity was thought to be due to the sample preparation protocol, sample storage, condition effects and that ware supported by the low results of total phenol and flavonoid content. The free radical-scavenging activity of phenol compounds 
follows the law or rules of the tructure activity relationship. Thus, phenol compounds with more hydroxyl groups will have more hydrogens to bind free radicals. ${ }^{13}$ There were a correlation between total phenol content and $\mathrm{IC}_{50}$, where if the total phenol is high, the $\mathrm{IC}_{50}$ value will be low and the antioxidant activity will be strong. This is due to the high number of existing polyphenol constituents that are able to function as antidotes to free radicals. ${ }^{14}$

Table 1. Average yield, total phenol, total flavonoid and antioxidant activity.

\begin{tabular}{|c|c|c|c|c|}
\hline Fraction & Rendement (\%) & $\begin{array}{l}\text { Total phenol } \\
\text { (mg GAE/g) }\end{array}$ & Total flavonoid (\%) & Antioxidant activity $\left(\mathrm{IC}_{50}\right)$ \\
\hline Ethanol & $19.40 \pm 1.33^{\mathrm{b}}$ & $9.75 \pm 0.22^{b}$ & $7.86 \pm 0.12^{\mathrm{b}}$ & $480.25 \pm 74.74^{b}$ \\
\hline$n$-hexane & $13.31 \pm 2.77^{\mathrm{b}}$ & $10.82 \pm 0.59^{\mathrm{a}}$ & $12.97 \pm 0.36^{\mathrm{a}}$ & $469.50 \pm 19.13^{b}$ \\
\hline Ethyl acetate & $33.81 \pm 6.03^{\mathrm{a}}$ & $5.26 \pm 0.26^{\mathrm{c}}$ & $1.88 \pm 0.26^{\mathrm{c}}$ & $3221.07 \pm 138.69^{a}$ \\
\hline
\end{tabular}

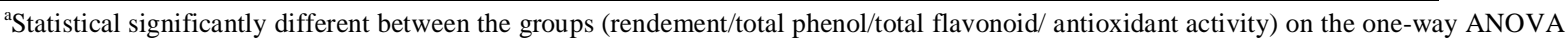
test $\mathrm{p}<0.001$.

${ }^{\mathrm{b}}$ Statistical significantly different between the total phenol/ total flavonoid on the one-way ANOVA test $\mathrm{p}<0.001$.

${ }^{\mathrm{c}}$ Statistical Statistical significantly different between the total phenol/ total flavonoid on the one-way ANOVA test $\mathrm{p}<0.001$.

Compound identification using gas and $n$-hexane) were then analyzed to determine the chromatography-mass spectrometry(GC-MS). chemical composition using GC-MS. The GC-MS After determination of the total phenol and total chromatograms for each of the fractions of sea flavonoid content of sea bamboo (I. hippuris), the bamboo axis are presented in figures 1,2 and 3.

content within each fraction (ethanol, ethyl acetate,

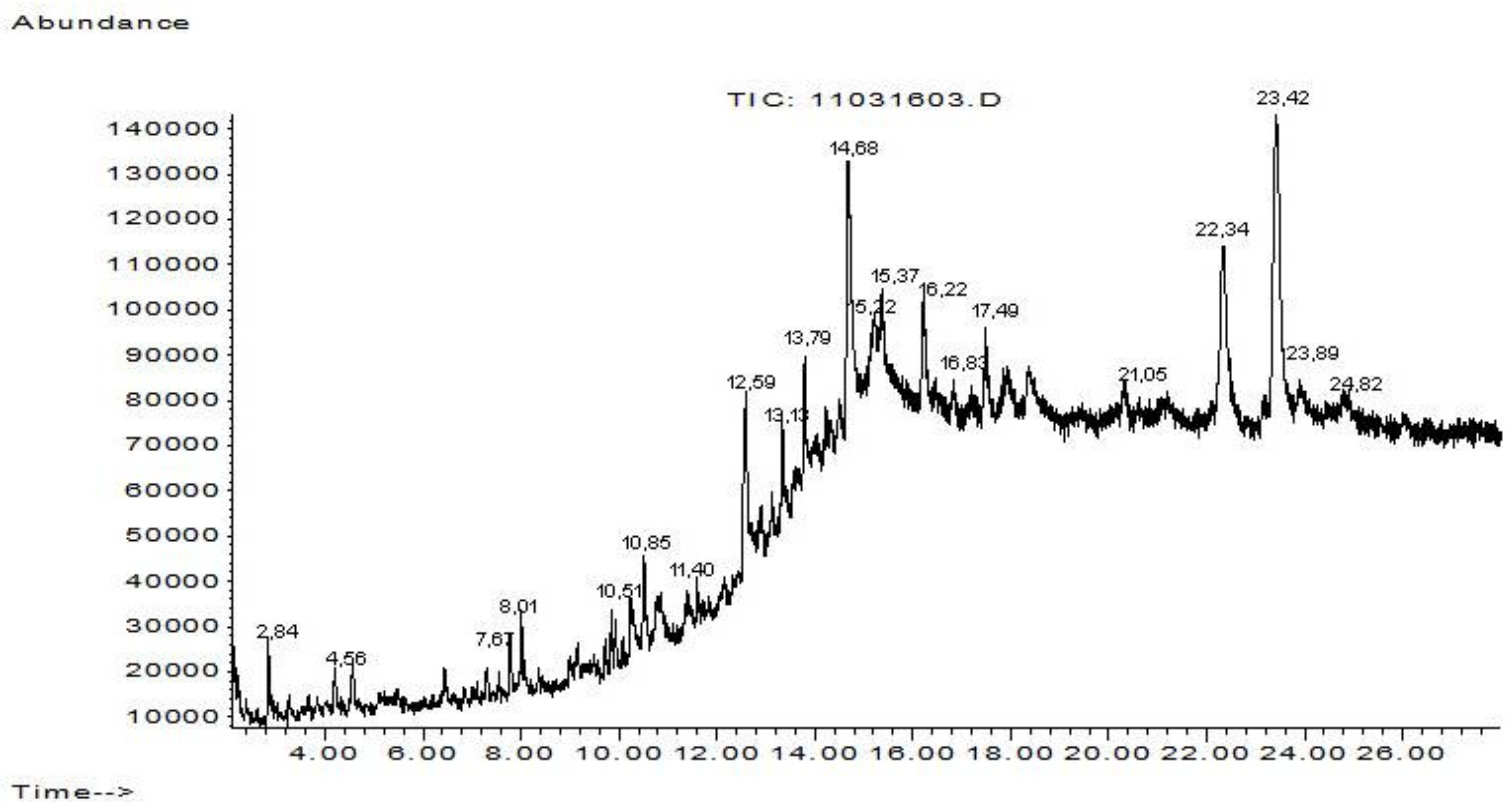

Figure 1. GC-MS chromatogram for the ethanol fraction of sea bamboo (I. hippuris) axis. 


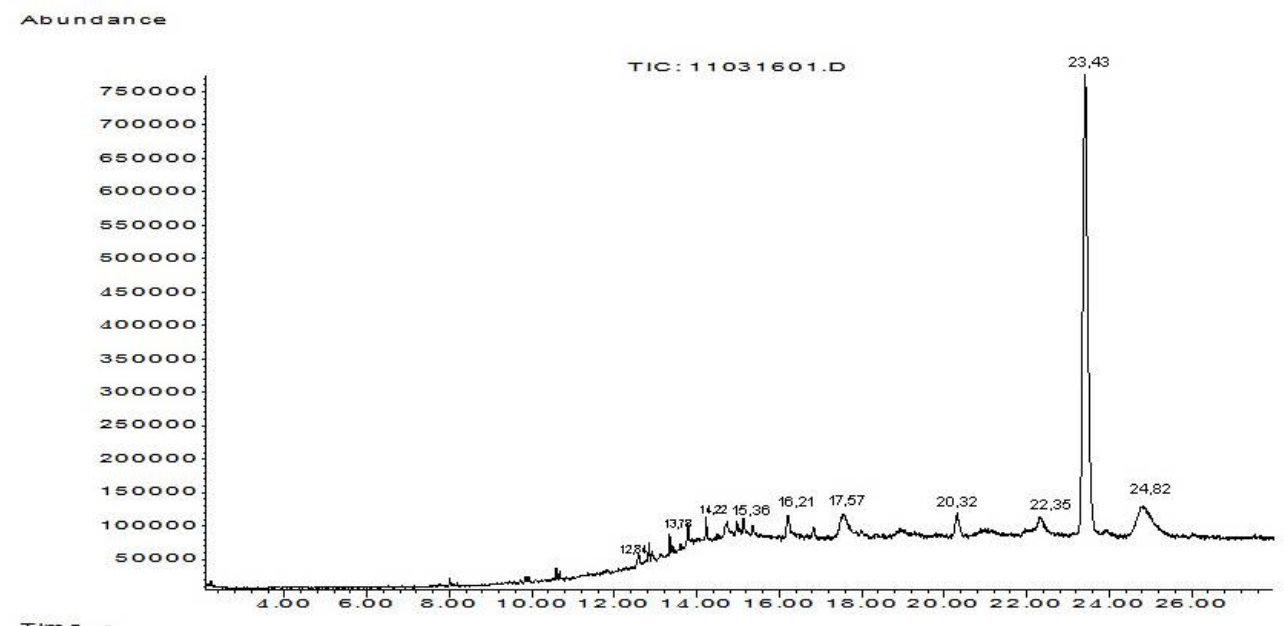

Figure 2. GC-MS chromatogram for the $n$-hexane fraction of sea bamboo (I. hippuris) axis.

Abundance

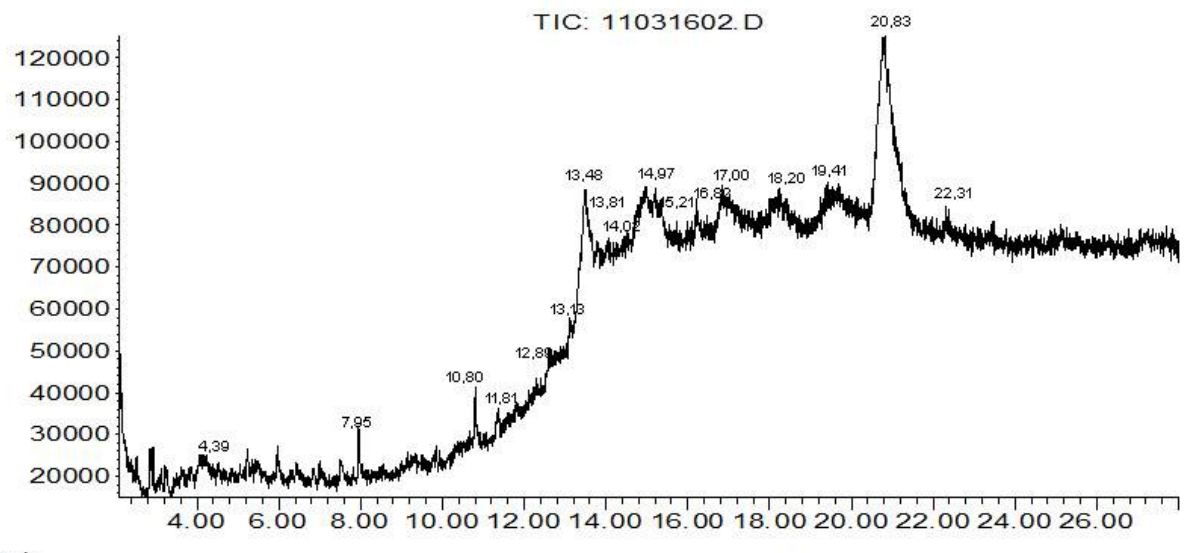

Time-->

Figure 3. GC-MS chromatogram for the ethyl acetate fraction of sea bamboo (I. hippuris) axis.

Based on the number of compounds identified, there were only a few compounds with greater than $90 \%$ similarity to compounds in the Wiley 275 L mass spectral library and NIST/EPA/NIH mass spectral library (NIST 02), and these were thought to be compounds that contribute to the antioxidant activity. The predominant chemical compounds within each of the fractions of sea bamboo (I. hippuris) axis are presented in table 2 .

As presented in table 2, there were several dominant compounds in the axis section of sea bamboo. One of the most prevalent compounds in the ethanol and $n$-hexane fraction of sea bamboo axis was hexanedioic acid. Hexanedioic acid or adipic acid, may have antibacterial ${ }^{15}$, and biological labeling. ${ }^{16}$

The other dominant compound in the ethanol extract of sea bamboo axis was $n$-hexadecanoic acid, which is also known as palmitic acid. This compound confers benefits as it acts as an antioxidant and a cytoprotective agent. ${ }^{17}$ The $n$-hexadecanoic acid or palmitic acid, is an aliphatic ester acid that can inhibit growth and induce apoptosis in human gastric cancer cells $^{18}$, and can also act as an antifungal ${ }^{19-20}$, and antimicrobial agent. ${ }^{21}$

In the $n$-hexane fraction of sea bamboo axis, we identified 9-octadecenoic acid, a compound which has anti-inflammatory, hypocholesterolemic, cancer 
preventive, hepatoprotective, nematicide, insectifuge, antihistamine, antieczema, antiacne, 5-alphareductase inhibitor antiandrogenic, antiarthritic and coronary protective effects. ${ }^{22}$ Moreover, 1,2-benzene dicarboxylic acid, which also has antimicrobial and antifouling activities, has also been found in the axis section of sea bamboo. ${ }^{23}$

The predominant compound of sea bamboo axis in the ethyl acetate fraction was 7-oxabicyclo[4.1.0] heptane, also known as cyclohexene oxide, which is a cycloaliphatic compound which can undergo cationic polymerization to form poly (cyclohexene oxide). Similar to the monovalent cyclohexene, poly (cyclohexene oxide) is a thermoplastic. Cyclohexene oxide has been studied extensively with analytical methods, showing a good reaction picture. ${ }^{24}$ Cyclohexene oxide is used as an ingredient for chemical analysis, especially as a catalyst. ${ }^{25}$

Table 2. Dominant compounds based on the fractionation test results of the extracted sea bamboo (I. hippuris) axis using GC-MS (\% relative is higher than $2 \%$ ).

\begin{tabular}{|c|c|c|c|c|c|c|}
\hline \multirow[t]{2}{*}{ No } & \multirow[t]{2}{*}{ IUPAC Name } & \multirow[t]{2}{*}{ Formula } & \multirow{2}{*}{$\begin{array}{l}\text { Molecule } \\
\text { Weight }\end{array}$} & \multicolumn{3}{|c|}{$\%$ Relative fraction } \\
\hline & & & & Ethanol & $\begin{array}{l}\text { Ethyl } \\
\text { acetate }\end{array}$ & $n$-hexane \\
\hline 1. & Hexanedioic acid & $\mathrm{C}_{6} \mathrm{H}_{10} \mathrm{O}_{4}$ & 146.06 & 11.85 & - & 41.99 \\
\hline 2. & 7-Oxabicyclo[4.1.0]heptanes & $\mathrm{C}_{6} \mathrm{H}_{10} \mathrm{O}$ & 98.14 & - & 28.27 & - \\
\hline 3. & 1,2-Benzenedicarboxylic acid & $\mathrm{C}_{8} \mathrm{H}_{6} \mathrm{O}_{4}$ & 166.13 & - & 14.77 & 3.88 \\
\hline 4. & $\begin{array}{l}\text { cis-8-(N-pyrrolidyl)-(2,2,5,5- } \\
\text { tetradeutero)bicyclo[4.3.0]nona-3,7-diene }\end{array}$ & $\mathrm{C}_{13} \mathrm{H}_{15} \mathrm{D}_{4} \mathrm{~N}$ & 193.32 & - & 9.98 & - \\
\hline 5. & Azetidine & $\mathrm{C}_{3} \mathrm{H}_{7} \mathrm{~N}$ & 57.09 & - & - & 9.89 \\
\hline 6. & Acetamide & $\mathrm{C}_{2} \mathrm{H}_{5} \mathrm{NO}$ & 59.07 & 9.46 & - & - \\
\hline 7. & $n$-Hexadecanoic acid & $\mathrm{C}_{16} \mathrm{H}_{32} \mathrm{O}_{2}$ & 256.42 & 9.22 & - & - \\
\hline 8. & 1-Octadecene & $\mathrm{C}_{18} \mathrm{H}_{36}$ & 252.48 & - & - & 8.36 \\
\hline 9. & Hexahydropyridine & $\mathrm{C}_{5} \mathrm{H}_{11} \mathrm{~N}$ & 85.15 & - & 7.86 & - \\
\hline 10. & Thiosulfuric acid & $\mathrm{H}_{2} \mathrm{O}_{3} \mathrm{~S}_{2}$ & 114.14 & 7.22 & - & - \\
\hline 11. & $\begin{array}{l}\text { Tricyclo[9.3.1.1(4,8)]hexadeca-1(15),4,6,8(16),11,13- } \\
\text { hexaene }\end{array}$ & $\mathrm{C}_{16} \mathrm{H}_{16}$ & 208.30 & - & 5.93 & - \\
\hline 12. & 8,12-Epoxy-13,14,15,16,17,19-hexanorlabdane & $\mathrm{C}_{14} \mathrm{H}_{24} \mathrm{O}$ & 208.34 & - & 5.19 & - \\
\hline 13. & 1H-Indole & $\mathrm{C}_{8} \mathrm{H}_{7} \mathrm{~N}$ & 117.15 & - & 5.08 & - \\
\hline 14. & $\begin{array}{l}\text { 6,7-Dihydro-2-methylamino-4H-oxazolo[3,2-a]-1,3,5- } \\
\text { triazin-4-one }\end{array}$ & $\mathrm{C}_{6} \mathrm{H}_{8} \mathrm{~N}_{4} \mathrm{O}_{2}$ & 168.15 & 4.99 & - & - \\
\hline 15. & Ethyl p-methoxycinnamate & $\mathrm{C}_{12} \mathrm{H}_{14} \mathrm{O}_{3}$ & 206.24 & 4.73 & - & - \\
\hline 16. & 5-Methyl-3-methoxy-7-nitroindazole & $\mathrm{C}_{9} \mathrm{H}_{9} \mathrm{~N}_{3} \mathrm{O}_{3}$ & 207.19 & - & 4.48 & - \\
\hline 17. & Propanedinitrile & $\mathrm{C}_{3} \mathrm{H}_{2} \mathrm{~N}_{2}$ & 66.06 & 4.25 & - & - \\
\hline 18. & Hexadecanoic acid & $\mathrm{C}_{16} \mathrm{H}_{32} \mathrm{O}_{2}$ & 256.42 & - & - & 4.08 \\
\hline 19. & 9-Octadecenoic acid & $\mathrm{C}_{18} \mathrm{H}_{34} \mathrm{O}_{2}$ & 282.46 & - & - & 3.69 \\
\hline 20. & 1H-Cyclopenta[a]pentalen-7-ol & $\mathrm{C}_{11} \mathrm{H}_{8} \mathrm{O}$ & 156.18 & 3.23 & - & - \\
\hline 21. & 2-(5'-Nitro-2'-thienyl)pyrimidine & $\mathrm{C}_{8} \mathrm{H}_{5} \mathrm{~N}_{3} \mathrm{O}_{2} \mathrm{~S}$ & 207.21 & 3.21 & - & - \\
\hline 22. & Cyclotetradecane & $\mathrm{C}_{14} \mathrm{H}_{28}$ & 196.37 & 2.99 & - & 3.13 \\
\hline 23. & 2H-1-Benzopyran-4-ol & $\mathrm{C}_{9} \mathrm{H}_{8} \mathrm{O}_{2}$ & 148.16 & - & - & 3 \\
\hline 24. & 1,3-Dimethyl-4-azaphenanthrene & $\mathrm{C}_{15} \mathrm{H}_{13} \mathrm{~N}$ & 207.27 & - & 2.98 & - \\
\hline 25. & 1-Docosanol & $\mathrm{C}_{22} \mathrm{H}_{46} \mathrm{O}$ & 326.6 & 2.51 & - & - \\
\hline 26. & Isometheptene & $\mathrm{C}_{9} \mathrm{H}_{19} \mathrm{~N}$ & 141.25 & - & 2.39 & - \\
\hline 27. & 1,13-Tetradecadiene & $\mathrm{C}_{14} \mathrm{H}_{26}$ & 194.36 & - & - & 2.33 \\
\hline 28. & Phloroglucinol & $\mathrm{C}_{6} \mathrm{H}_{6} \mathrm{O}_{3}$ & 126.11 & 2.29 & - & - \\
\hline 29. & 1,2-Benzisothiazole & $\mathrm{C}_{7} \mathrm{H}_{5} \mathrm{NS}$ & 135.19 & - & - & 2.21 \\
\hline 30. & Cyclotrisiloxane & $\mathrm{H}_{6} \mathrm{O}_{3} \mathrm{Si}_{3}$ & 138.30 & - & 2.16 & - \\
\hline
\end{tabular}

The most dominant compounds of skin (outer layer) of sea bamboo in ethanol fraction were 2butoxyethanol (43.68\%), hexanedioic acid (12.11\%), for the ethyl acetate fraction were 2-myristynoylglycinamide (19.51\%), 1H-indole (17.64\%), 8ß.,12epoxy-13,14,15,16,17,19-hexanorlabdane/2(1H)- 
naphthalenone, octahydro-4a-methyl-7-(1- methylethyl) $(11.63 \%)$, while for the $n$-hexane fraction, the most dominant compounds were methyldmannopyranoside (20.41\%), 2,6-dimethyl-3(methoxymethyl)-benzoquinone $(8.16 \%){ }^{26}$

\section{CONCLUSION}

Based on the results of this study, we can conclude that $n$-hexane, ethanol and ethyl acetate fractions of sea bamboo (I. hippuris) axis extract have low total phenol and total flavonoid contents. Similarly, the antioxidant activity of each fraction is also low. The predominant compound identified by GC-MS in the ethanol and $n$-hexane fractions was hexanedioic acid, while that for the ethyl acetate fraction was 7-oxabicyclo[4.1.0]heptane.

\section{ACKNOWLEDGEMENT}

The authors would like to thank the Ministry of Marine Affairs and Fisheries, Republic of Indonesia who has funded the implementation of this research.

\section{REFERENCES}

1. Murniasih, T. 2003. Metabolit sekunder dari spons sebagai bahan obat-obatan. J. Oseana 3, 27-33.

2. Tomascik, T. 1997. The ecology of the Indonesian Seas. Oxford University Press.

3. Manuputty, A. E. 2002. Karang lunak (soft coral) perairan Indonesia. Lembaga Ilmu Pengetahuan Indonesia, Pusat Penelitian Oseanografi, Proyek Pemanfaatan dan Diseminasi Iptek Kelautan.

4. Fabricius, K. K. and Alderslade, P. P. 2001. Soft corals and sea fans: a comprehensive guide to the tropical shallow water genera of the central-west Pacific, the Indian Ocean and the Red Sea. Australian Institute of Marine Science (AIMS).

5. Sayuti, M., Putri, W. D. R., and Yunianta. 2016. Phytochemical Screening and Antioxidant Activity Test of Isis hippuris Methanol Extract. Int. J. Chem.Tech. Res. 9, 427-434.

6. Yangthong, M., Hutadilok-Towatana, N. and Phromkunthong, W. 2009. Antioxidant activities of four edible seaweeds from the southern coast of Thailand. Plant Foods for Human Nutrition 64, 218-223.

7. Sharma, G. N., Dubey, S. K., Sati, N. and Sanadya, J. 2011. Phytochemical screening and estimation of total phenolic content in Aegle marmelos seeds. Int. J. Pharm. Clin. Res. 3, 27-29.
8. Santoso, J., Anwariyah, S., Rumiantin, R. O., Putri, A. P., Ukhty, N. and Yoshie-Stark, Y. 2012. Phenol content, antioxidant activity and fibers profile of four tropical seagrasses from Indonesia. J. Coastal Dev. 15, 189-196.

9. Chang, C. C., Yang, M. H., Wen, H. M. and Chern, J. C. 2002. Estimation of total flavonoid content in propolis by two complementary colorimetric methods. J. Food Drug Anal. 10.

10. Hassan, S. M., Al Aqil, A. A. and Attimarad, M. 2013. Determination of crude saponin and total flavonoids content in guar meal. Adv. Med. Plant Res. 1, 24-28.

11. Nugroho, A. E., Malik, A. and Pramono, S. 2013. Total phenolic and flavonoid contents, and in vitro antihypertension activity of purified extract of Indonesian cashew leaves (Anacardium occidentale L.). Int. food Res. J. 20.

12. Molyneux, P. 2004. The use of the stable free radical diphenylpicrylhydrazyl (DPPH) for estimating antioxidant activity. Songklanakarin J. Sci. Technol. 26, 211-219.

13. Shahidi, F., Janitha, P. K. and Wanasundara, P. D. 1992. Phenolic antioxidants. Critical Reviews in Food Science and Nutrition 32, 67-103.

14. Chew, Y. L., Lim, Y. Y., Omar, M. and Khoo, K. S. 2008. Antioxidant activity of three edible seaweeds from two areas in South East Asia. LWT-Food Sci. Tech. 41, 1067-1072.

15. Choi, W. H., and Jiang, M. 2014. Evaluation of antibacterial activity of hexanedioic acid isolated from Hermetia illucens larvae. Journal of applied biomedicine, 12 (3), 179-189.

16. Zhang, Q., Song, K., Zhao, J., Kong, X., Sun, Y., Liu, X., Zhang, Y., Zeng, Q. and Zhang, H. 2009. Hexanedioic acid mediated surface-ligand-exchange process for transferring NaYF4: Yb/Er (or Yb/Tm) up-converting nanoparticles from hydrophobic to hydrophilic. J. Colloid Interface Sci. 336,, 171-175.

17. Kumar, P. P., Kumaravel, S. and Lalitha, C. 2010. Screening of antioxidant activity, total phenolics and GC-MS study of Vitex negundo. African J. Biochem. Res. 4, 191-195.

18. Yu, F. R., Lian, X. Z., Guo, H. Y., McGuire, P. M., Li, R. D., Wang, R. and Yu, F. H. 2005. Isolation and characterization of methyl esters and derivatives from Euphorbia kansui (Euphorbiaceae) and their inhibitory effects on the human SGC-7901 cells. J. Pharm. Pharm. Sci. 8, 528-35.

19. Abubacker, M. N. and Deepalakshmi, T. 2013. In vitro antifungal potential of bioactive compound methyl ester of hexadecanoic acid isolated from Annona muricata Linn (Annonaceae) leaves. Biosciences Biotechnol. Res. Asia 10, 879-884.

20. Pohl, C. H., Kock, J. L. and Thibane, V. S. 2011. Antifungal free fatty acids: a review. Science Against Microb. Pathogens: Communi. Curr. Res. Technol. Adv. 3, 61-71. 
21. Gobalakrishnan, R., Manikandan, P. and Bhuvaneswari, R. 2014. Antimicrobial potential and bioactive constituents from aerial parts of Vitis setosa Wall. J. Med. Plants Res. 8, 454-460.

22. Bendiabdellah, A., Dib, M. E. A., Meliani, N., Muselli, A., Nassim, D., Tabti, B., and Costa, J. 2012. Antibacterial activity of Daucus crinitus essential oils along the vegetative life of the plant. J. Chem. 2013, 1-7.

23. Kalaivani, C. S., Sathish, S. S., Janakiraman, N. and Johnson, M. 2012. GC-MS studies on Andrographis paniculata (Burm. f.) Wall. ex Nees-A medicinally important plant. Int. J. Med. Arom. Plants 2, 69-74.
24. Ibberson, R. M., Yamamuro, O. and Tsukushi, I. 2006. The crystal structures and phase behaviour of cyclohexene oxide. Chem. Physics Letters 423, 454-458.

25. Yahiaoui, A., Belbachir, M., Soutif, J. C. and Fontaine, L. 2005. Synthesis and structural analyses of poly (1, 2cyclohexene oxide) over solid acid catalyst. Materials Letters 59, 759-767.

26. Sayuti, M., Putri, W. D. R. and Yunianta. 2017. Antioxidant Activity and Identification of Compounds in the Extract of Sea Bamboo's (Isis hippuris) Outer Layer. Res. J. Pharm, Biol. Chem. Sci. July-August 8, 884-897. 